\title{
Redistribution of iron and hydrogen peroxide in Pinus sylvestris roots in response to trophically diverse fungi
}

\author{
Joanna Mucha • Anna Napierala-Filipiak • \\ Elżbieta Gabała • Tomasz Andrzej Pawłowski • \\ Marcin Zadworny
}

Accepted: 18 November 2018 / Published online: 5 December 2018

(C) The Author(s) 2018

\begin{abstract}
The simultaneous over-accumulation of $\mathrm{Fe}$, hydrogen peroxide and superoxide can result in the generation of hydroxyl radicals, which play a significant role in the interactions between plant hosts and invading fungi. The physiological response to infection by pathogenic or mycorrhizal fungi may, however, be determined by the root zone. The objective of the present study was to use light microscopy to determine whether iron and hydrogen peroxide are differentially distributed in P. sylvestris roots in response to colonization by necrotrophic pathogens (Fusarium oxysporum and Rhizoctonia solani) vs. mycorrhizal fungi (Hebeloma crustuliniforme and Laccaria bicolor) in in vitro culture. It was also of interest to determine how hydrogen peroxide, superoxide, and iron added to substrate in vitro impacted the ability of trophically different fungi to grow. Infection by necrotrophic fungi, especially by F. oxysporum, were associated with a significantly higher accumulation of both forms of iron $\left(\mathrm{Fe}^{2+}\right.$ and $\mathrm{Fe}^{3+}$ ) in the meristematic root zone, relative to the accumulation of these forms of iron in response to ectomycorrhizal fungi. Iron supplementation of solid culture medium reduced the growth of pathogenic fungi
\end{abstract}

J. Mucha $(\bowtie) \cdot$ A. Napierała-Filipiak · T. A. Pawłowski • M. Zadworny

Institute of Dendrology, Polish Academy of Science, Parkowa 5, 62-035 Kórnik, Poland

e-mail: jmucha@man.poznan.pl

E. Gabała

Institute of Plant Protection, National Research Institute, Wegorka 20, 60-318 Poznań, Poland to a greater extent than the growth of mycorrhizal fungi. In contrast to the distribution of iron, cells in the elongation zone of $P$. sylvestris roots generally exhibited the highest accumulation of hydrogen peroxide. The growth of mycorrhizal fungi was more inhibited by the presence of hydrogen peroxide in the solid culture medium than by any other supplemented compounds. This research indicate that the distribution of iron and hydrogen peroxide in roots of $P$. sylvestris is related to the trophic strategy of the colonizing fungi.

Keywords Iron · Hydrogen peroxide · Ectomycorrhizal fungi $\cdot$ Pathogenic fungi $\cdot$ Gymnosperm

\section{Introduction}

Plants are constantly challenged by microorganisms and their interactions range from parasitism to mutualism. Mechanisms associated with plant defense responses to trophically different fungi have been extensively studied. It has been generally recognized that a considerable variation exists in the extent of the formation of reactive oxygen species (ROS) at the initial stage of the interaction and that this initial response can determine the nature of the subsequent association (Asiegbu et al. 1999; Adomas et al. 2008; Zhang and Tang 2012). ROS accumulation can lead to a hypersensitive response and cell death in plant hosts, which functions as a defense mechanism against biotrophic pathogens, but fosters plant colonization by necrotrophic pathogens (Govrin and Levine 2000). ROS accumulation in host 
tissues resulting from the colonization of fungi establishing a mutualistic association (e.g. mycorrhizal fungi), however, does not appear to result in the massive death of plant cells (Baptista et al. 2007; Mucha et al. 2014). Thus, specific redox levels associated with reactive oxygen species, as well as levels of iron, during plant-fungus interactions may either foster or prevent fungal establishment and disease. Iron levels also play a role in formation of hydroxyl radicals (Pierre and Fontecave 1999; Baker and Orlandi 1995) but whether the relationship between iron and hydrogen peroxide accumulation in plant roots differs between trophically different fungi (necrotrophic vs. mycorrhizal fungi) is relatively unknown.

Mechanisms regulating iron homeostasis in pathogenic and symbiotic fungi are not well understood. Acquisition of iron is necessary for the growth and development of fungal pathogens, and iron plays an essential role in activating the transcription of fungal pectinase genes that are engaged in the infection process (Expert 1999; Franza et al. 2002, 2005). Thus, fungal pathogens that can acquire iron from their hosts when the available iron in the environment is limiting are at a distinct advantage. Fungi utilize two processes to regulate iron accumulation; specifically, a reduction in iron assimilation and siderophore-assisted iron uptake. The mechanism utilized to acquire iron from plant tissues depends on the nature of the plant-fungus interaction (Eichhorn et al. 2006; Greenshields et al. 2007; Oide et al. 2006; Schrettl et al. 2004; Ramanan and Wang 2000), suggesting that separate strategies may exist for biotrophic vs. necrotrophic pathogens (Greenshields et al. 2007). Indeed, fungal siderophores can act as virulence determinants in necrotrophs (Oide et al. 2006; Schrettl et al. 2004), but also play a role in maintaining beneficial plant-fungal interactions (Johnson et al. 2007). Although ectomycorrhizal fungi are capable of producing siderophores (Haselwandter 1995; Renshaw et al. 2002), how iron accumulation in plant cells reflects the relationship between a plant and fungi with different trophic strategies at the initial stage is not known.

ROS catalysis by a small "transit" pool of cellular iron is possible (Johnson 2008) where $\mathrm{Fe}^{2+}$ is oxidized by hydrogen peroxide to $\mathrm{Fe}^{3+}$, resulting in the formation of a harmful hydroxyl radicals (Pierre and Fontecave 1999). The distribution of iron in host cells and tissues may act as a defense signal in plant cells and induce the activation of many host defense systems against an invading pathogen (Dellagi et al. 2009); including those involved in oxidative metabolism (Johnson 2008). For example, targeted alterations in iron homeostasis associated with the production of $\mathrm{H}_{2} \mathrm{O}_{2}$ induce the expression of pathogenesis-related genes as a part of the defense response in leaves of Blumeria graminis (DC). Speer f. sp. tritici Marchal (Liu et al. 2007). The processes associated with plant defense responses can either assist the plant in resisting pathogen invasion, or may actually benefit the establishment and spread of a fungal pathogen.

In roots, meristematic and elongation zones differ in their anatomy and functional physiological roles (Scheres et al. 2002). These differences make the meristematic zone of root tips more conducive to the colonization of necrotrophs (Rodriguez-Galvez and Mendgen 1995) than ectomycorrhizal fungi (Felle et al. 2009). Our previous results demonstrated that a hypersensitive response related to $\mathrm{Fe}$ and $\mathrm{H}_{2} \mathrm{O}_{2}$ can regulate the initial stage of $P$. sylvestris root infection by the pathogen, Heterobasidion annosum s.s. (Mucha et al. 2012). It was subsequently demonstrated that an iron-dependent mechanism primarily operates in the meristematic zone of $P$. sylvestris roots invaded by $H$. annosum s.s., and to a much lesser extent, in roots invaded by pathogens (H. parviporum and $H$. abietinum) that are more atypical for $P$. sylvestris (Mucha et al. 2015). It is unclear, however, whether iron levels, and its distribution in different root zones, is another factor that impacts the redox state in trophically diverse fungus - plant root interactions.

The initial stages of the interaction between plants and trophically different fungi may be determined by the dynamics of iron accumulation. A model that accounts for ROS and $\mathrm{Fe}$ dynamics between a host and an invading fungus may more accurately reflect the strategy of a necrotrophic fungus vs. a mutualistic symbiont. The objective of the present study was to determine whether the accumulation and distribution of iron and hydrogen peroxide in plant host tissues is affected by trophically diverse fungal species (necrotrophic pathogens vs. ectomycorrhizal fungi). We also hypothesize that ectomycorrhizal fungi will be more sensitive to hydrogen peroxide than to superoxide or iron, as compared to necrotrophic fungi that will be more restricted by hydrogen peroxide and iron than ectomycorrhizal fungi. 


\section{Material and methods}

Plant material and experimental design

The seeds of Scots pine (Pinus sylvestris L.) used in the current study originated from the provenance of Bolewice, Poland $\left(52^{\circ} 28^{\prime} \mathrm{N}\right.$ and $\left.16^{\circ} 03^{\prime} \mathrm{E}\right)$. Laccaria bicolor (Maire) P.D. Orton and Hebeloma crustuliniforme (Bull.) Quél. and two isolates of the fungal pathogens, Fusarium oxysporum E.F. Sm. \& Swingle and Rhizoctonia solani J.G. Kühn were used to examine iron redistribution in response to trophically diverse fungal species. The strains of $F$. oxysporum and $R$. solani were isolated from a forest nursery in the Myslibórz Forest District (N 52 51'04", E 1451'44"). The ectomycorrhizal fungi were isolated from fruiting bodies growing in a forest near Sulęczyno (N 54 $13^{\prime} 30^{\prime \prime}$, E $\left.17^{\circ} 46^{\prime} 4^{\prime \prime}\right)$. All of the fungal isolates were maintained on malt extract agar (MEA) (malt agar extract, Difco, Detroit, MI, USA) in the dark. Plants were inoculated with the different fungi every 2 years and then reisolated in order to avoid a loss of infective properties due to long-term storage on artificial MEA media.

Scots pine seeds were sterilized with $0.1 \% \mathrm{HgCl}_{2}(w / v)$ (Polish Chemical Reagents, Gliwice, Poland) for $3 \mathrm{~min}$, washed three times ( $5 \mathrm{~min}$ each) in sterile distilled water, and then germinated on $0.6 \%$ water agar (w/v) (Difco, Detroit, MI, USA) in the dark. Germinated seeds were subsequently transferred under sterile conditions to Ingestad medium (Ingestad 1979) in $14 \mathrm{~cm}$ (diameter) Petri dishes. Roots of one-week-old seedlings were covered with a piece of filter paper containing actively growing fungi and were then covered by cellophane foil to prevent desiccation. All manipulations were performed under sterile conditions. Seedlings were grown under fluorescent lights (Osram L36/W77 Flora; $100 \mu \mathrm{Em}^{-2} \mathrm{~s}^{-1}$ ) using a $16 \mathrm{~h}$ a day, $60 \% \mathrm{RH}$ and a $24: 20{ }^{\circ} \mathrm{C}$ day: night temperature regime. Roots of control plants were covered with sterile filter paper and cellophane foil. Pinus sylvestris roots were harvested at $2 \mathrm{~h}, 6 \mathrm{~h}, 24 \mathrm{~h}, 48 \mathrm{~h}, 96 \mathrm{~h}$, and $10 \mathrm{~d}$.

Light microscopy visualization of iron and hydrogen peroxide

The protocol described by Thordal-Christensen et al. (1997) was used to visualize ROS, mainly $\mathrm{H}_{2} \mathrm{O}_{2}$, in Scots pine roots. Prior to visualization of ROS with light microscopy, roots were submerged for $75 \mathrm{~min}$ in $1 \mathrm{mg} \mathrm{ml}^{-1}$ 3,3'-diaminobenzidine, $\mathrm{pH} 3.8$.
Iron accumulation in Scots pine roots was visualized using the protocol described by Smith et al. (1997) and Liu et al. (2007). Pieces of roots were placed in a fixative solution of methacarn (methanol:chloroform:acetic acid, 60:30:10) at $4{ }^{\circ} \mathrm{C}$ for $15 \mathrm{~h}$. Roots were then dehydrated in a graded series (70-100\%) of ethanol solutions and subsequently incubated in $7 \%$ potassium ferrocyanide for $24 \mathrm{~h}$ to detect $\mathrm{Fe}^{3+}$. In order to detect $\mathrm{Fe}^{2+}$, roots were incubated for $48 \mathrm{~h}$ in $7 \%$ potassium ferricyanide in aqueous $3 \%$ hydrochloric acid. Root samples were sectioned by hand, placed on glass slides, and observed under an Axioscope 20 microscope (Carl Zeiss, Jena, Germany) at a magnification of $40 x$.

\section{Stress tolerance assay}

Isolates of the fungal pathogens, $F$. oxysporum and $R$. solani, and the ectomycorrhizal fungi, L. bicolor and $H$. crustuliniforme, were grown on MEA (Difco, Detroit, MI, USA) supplemented with increasing concentrations $(1,5,10$ or $15 \mathrm{mM})$ of $\mathrm{H}_{2} \mathrm{O}_{2}$ or $\mathrm{KO}_{2}$ (superoxide generator), or the varying concentrations $(1,5,10$ or $15 \mathrm{mM}$ ) of $\mathrm{FeCl}_{3}$. Colony diameter was measured daily for all of the isolates growing in each of the concentrations of stress compounds to evaluate the sensitivity of each of the fungal species to the stress reagent. Results were expressed as a percentage of fungal colony growth relative to a control growing on non-amended medium.

Statistical analyses

All experiments utilized five biological replicates for each of the experimental units and each experiment was repeated three times. The number of cells exhibiting iron or hydrogen peroxide staining was used to calculate a percentage of cells with staining relative to the total number of cells observed in a field of view using the Bliss equation (Snedecor and Cochran 1967). A hierarchical analysis of variance was used to determine the significance of the effect of root zone (meristematic and elongation zone), fungal trophic strategy, fungal species nested in fungal trophic strategy, and length of time of the interaction. A one-way ANOVA, followed by a Tukey's HSD test, was used to determine significant differences between the time of sampling within an experimental unit (fungal strain) and among different root parts within the same time point for the different fungal strains. Pearson's correlation coefficients were 
used to determine the strength of the interdependence of the studied parameters. All statistical analyses were conducted using JMP 8 software (SAS Institute, Cary, $\mathrm{NC}, \mathrm{USA}$ ) and were considered significant at $P \leq 0.05$.

\section{Results}

Hydrogen peroxide $\left(\mathrm{H}_{2} \mathrm{O}_{2}\right)$

P. sylvestris infected with trophically diverse fungi exhibited an increase in the percentage of cells stained with $\mathrm{H}_{2} \mathrm{O}_{2}$, relative to the control (Table 1). The percentage of cells with $\mathrm{H}_{2} \mathrm{O}_{2}$ in $P$. sylvestris roots was not dependent on fungal trophic strategy but a strong influence was found for species nested within fungal trophic strategy $(P=0.004)$. The presence of mycorrhizal fungi caused a gradual increase in the percentage of cells with hydrogen peroxide. In contrast to the response of roots to ectomycorrhizal fungi, a high percentage of cells with hydrogen peroxide were present in roots of $P$. sylvestris seedlings in response to $R$. solani. Percentage of cells exhibiting $\mathrm{H}_{2} \mathrm{O}_{2}$ staining were also more frequently $(P<0.010)$ observed in the elongation zone than in the meristematic zone of roots. This zonation was largely evident in roots invaded by ectomycorrhizal fungi. The pathogenic fungus, F. oxysporum, induced a lower level of $\mathrm{H}_{2} \mathrm{O}_{2}$ accumulation in the elongation zone than in the meristematic zone. Percentage of stained cells of both zones was similar in roots infected with $R$. solani. Differences in $\mathrm{H}_{2} \mathrm{O}_{2}$ accumulation in P. sylvestris root cells in response to the presence of the studied fungal species was mainly observed at the later stages of the interaction time (48 $\mathrm{h}$ and later).

Ferric iron $\left(\mathrm{Fe}^{3+}\right)$

The pattern of accumulation of $\mathrm{Fe}^{3+}$ observed in roots was in contrast to those observed for hydrogen peroxide. $P$. sylvestris roots infected with fungal pathogens exhibited a greater percentage of cells with $\mathrm{Fe}^{3+}$ staining than roots colonized by mycorrhizal fungi. The lowest percentage of cells stained with ferric ion was observed in roots colonized by the ectomycorrhizal fungus, $H$. crustuliniforme, and the highest $(P<0.001)$ accumulation of cell with ferric ions was observed in roots infected with the fungal pathogen, F. oxysporum. Similar to the $\mathrm{H}_{2} \mathrm{O}_{2}$ response, a higher percentage of host cells exhibited $\mathrm{Fe}^{3+}$ staining in the elongation than in the meristematic zone $(P=0.023)$. Additionally, the number of stained cells increased with time $(P<0.001)$ (Table 2). Differential accumulation of $\mathrm{Fe}^{3+}$ in root cells of $P$. sylvestris in response to the trophically different fungi was observed at $2 \mathrm{~h}$ and at the latter sampled time points (48 h, $96 \mathrm{~h}$ and 10 days).

\section{Ferrous iron $\left(\mathrm{Fe}^{2+}\right)$}

Percentage of cell with $\mathrm{Fe}^{2+}$ in root of P. sylvestris was strongly dependent on fungal trophic strategy $(P<0.001)$, though percentage of cells with $\mathrm{Fe}^{2+}$ accumulation also varied in response to species nested within trophic strategy $(P<0.001)$. Pathogenic fungi induced the greatest accumulation of cell stained with $\mathrm{Fe}^{2+}$, and F. oxysporum induced the highest percentage of cell with $\mathrm{Fe}^{2+}$ between the two species of pathogenic fungi (Table 3). Percentage of cell with $\mathrm{Fe}^{2+}$ was higher in the meristematic zone than in the elongation zone of roots $(P=0.038)$ (Table 3$)$. This pattern, however, was only true for pathogenic fungi. No differences in zonal accumulation of percentage of cells with $\mathrm{Fe}^{2+}$ was observed in roots colonized by mycorrhizal fungi. In contrast to the accumulation of hydrogen peroxide and $\mathrm{Fe}^{3+}$, the percentage of root cells with $\mathrm{Fe}^{2+}$ staining significantly increased at the initial stage of the interaction $(2 \mathrm{~h})$, followed by a decrease $(6 \mathrm{~h})$, and reached a maximum percentage at 10 -day $(P<0.001)$ in roots infected with necrotrophic fungi.

Correlation coefficients for all of the studied fungi indicated that the percentage of cells exhibiting $\mathrm{H}_{2} \mathrm{O}_{2}$ staining in the elongation zone was positively correlated ( $r=0.40, P=0.044)$ with the percentage of cells exhibiting $\mathrm{Fe}^{3+}$ staining and negatively correlated $(r=$ $-0.41, P=0.038)$ with $\mathrm{Fe}^{2+}$ staining. A positive correlation $(r=0.54, P=0.005)$ was also observed between the percentage of cells exhibiting $\mathrm{H}_{2} \mathrm{O}_{2}$ and $\mathrm{Fe}^{3+}$ staining in the meristematic zone of roots.

\section{Stress tolerance to iron and ROS}

All of the stress-inducing compounds utilized in the current study inhibited the growth of both ectomycorrhizal and pathogenic fungi (Fig. 1). Growth inhibition was highly dependent on the concentration of the tested compound $(P<0.001)$ (Fig. 1). The highest level of inhibition of the fungal pathogen species, $F$. oxysporum and $R$. solani, was observed on MEA medium containing either hydrogen peroxide or iron. 


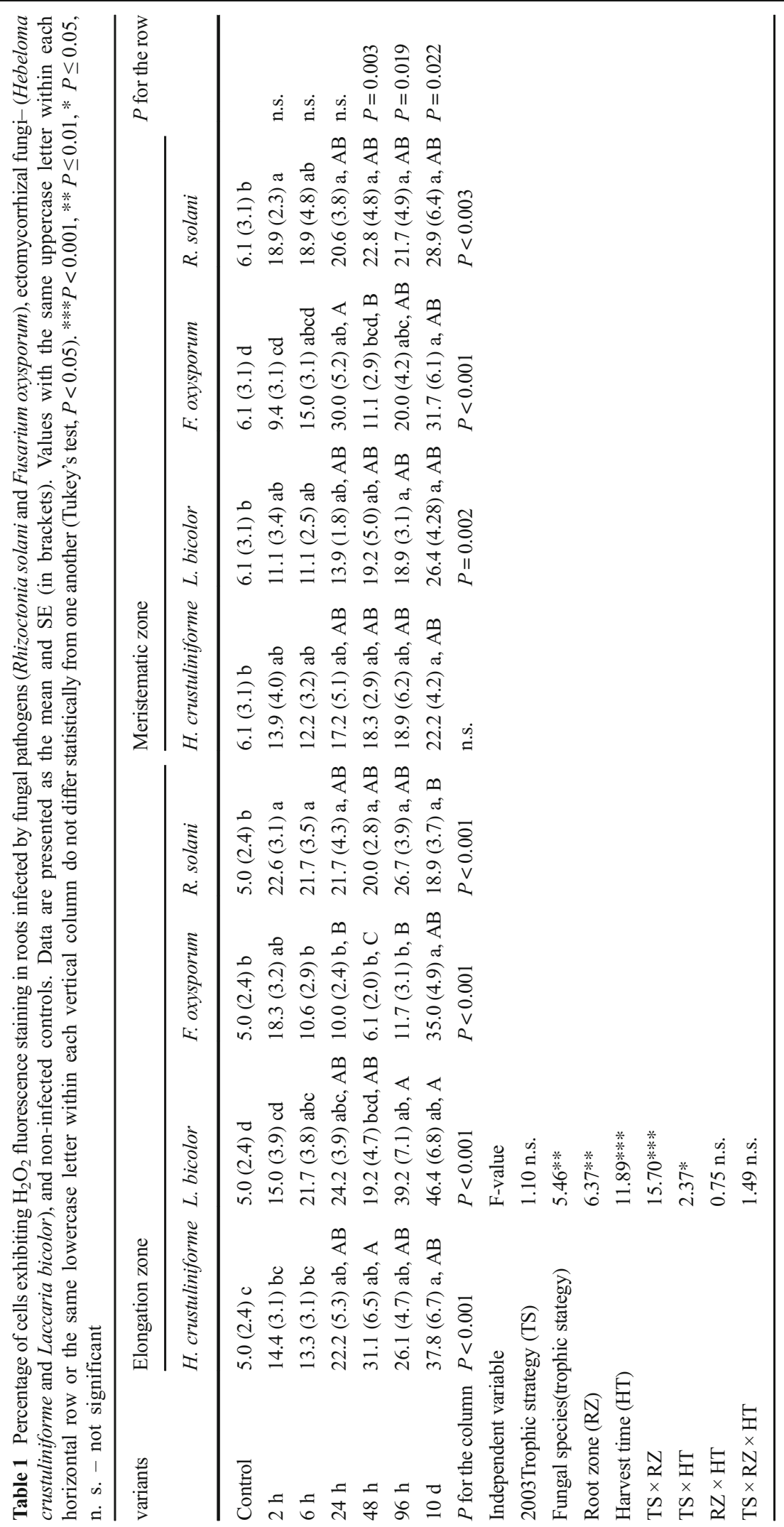




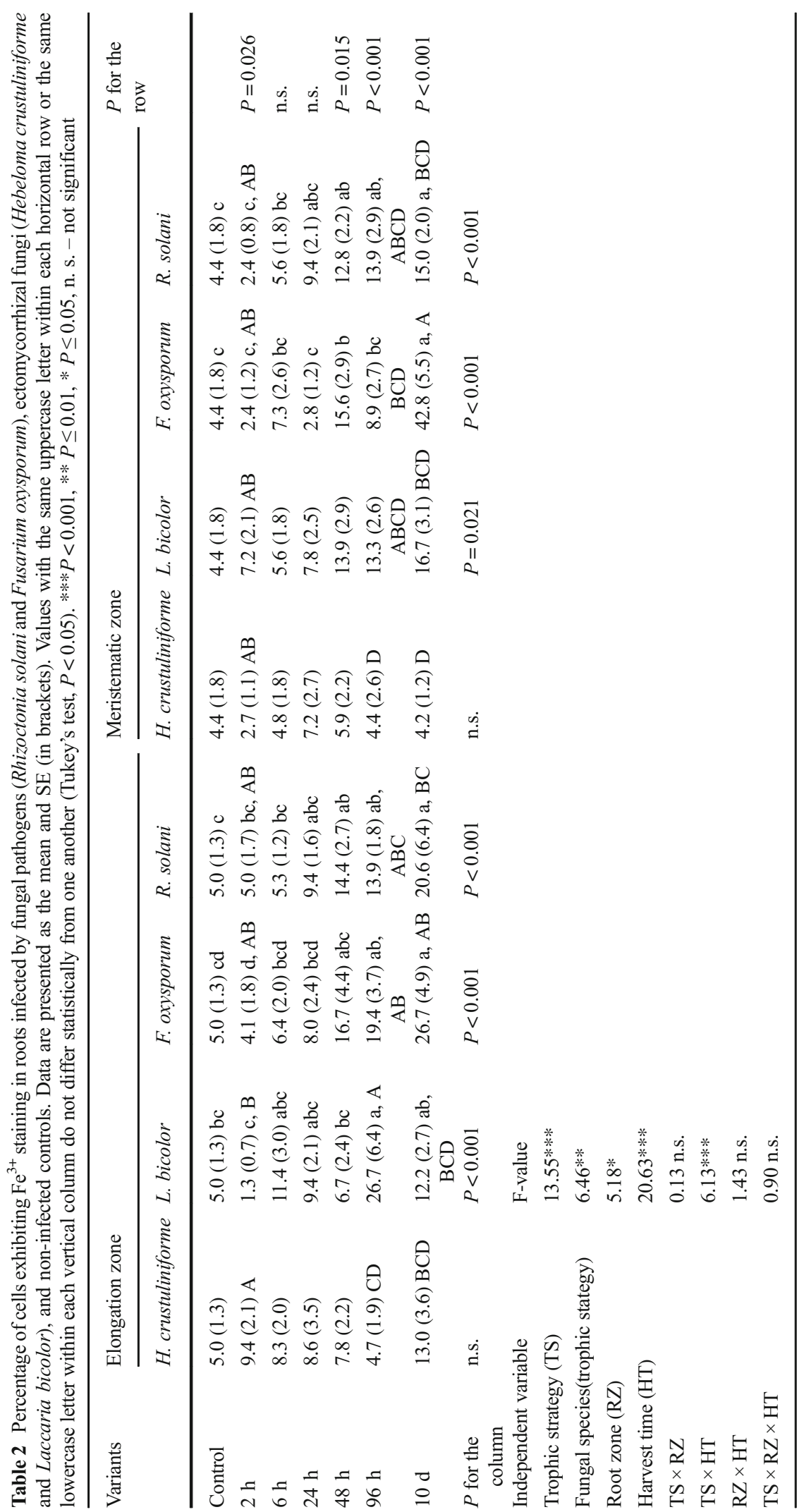




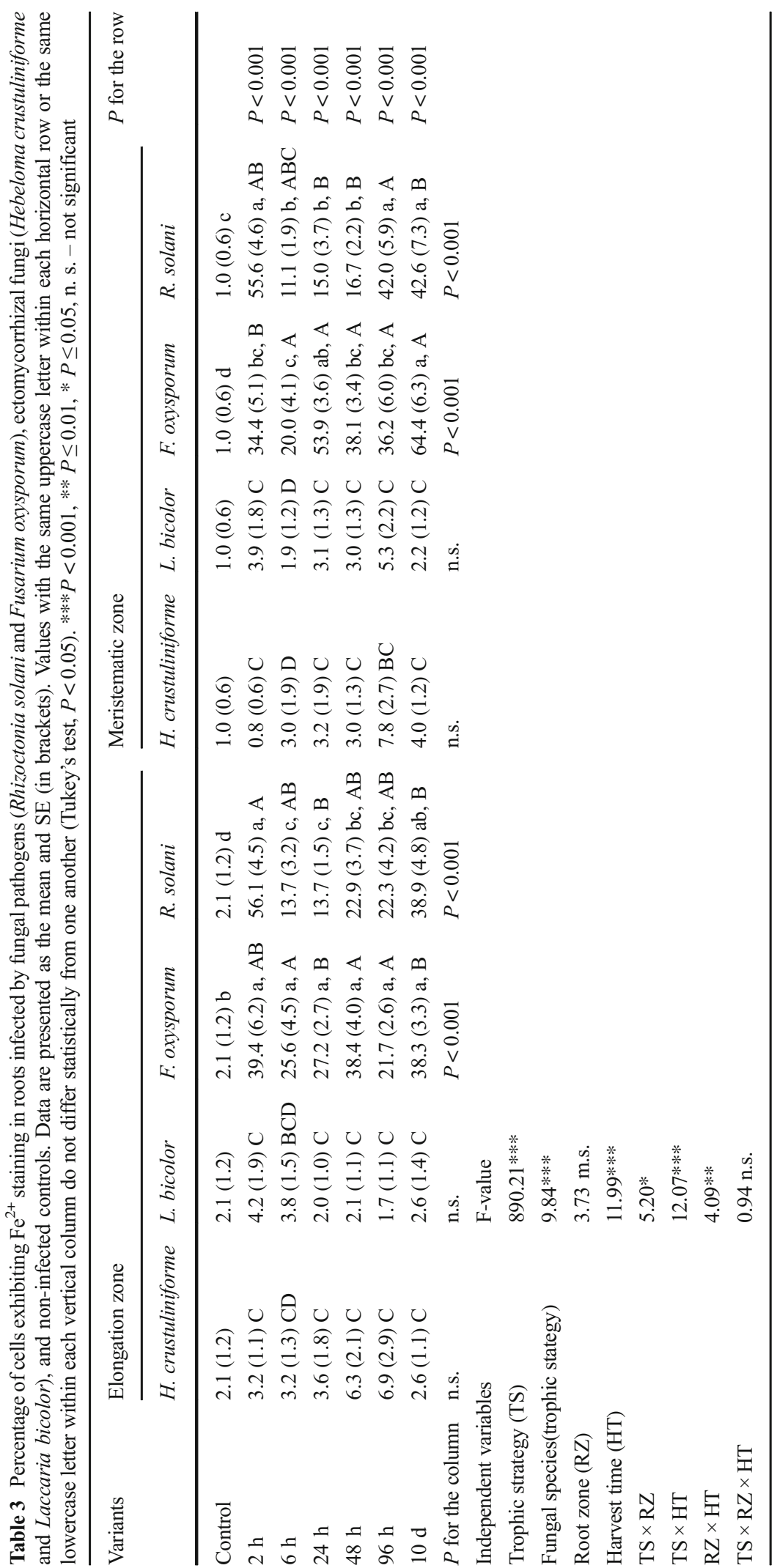


a

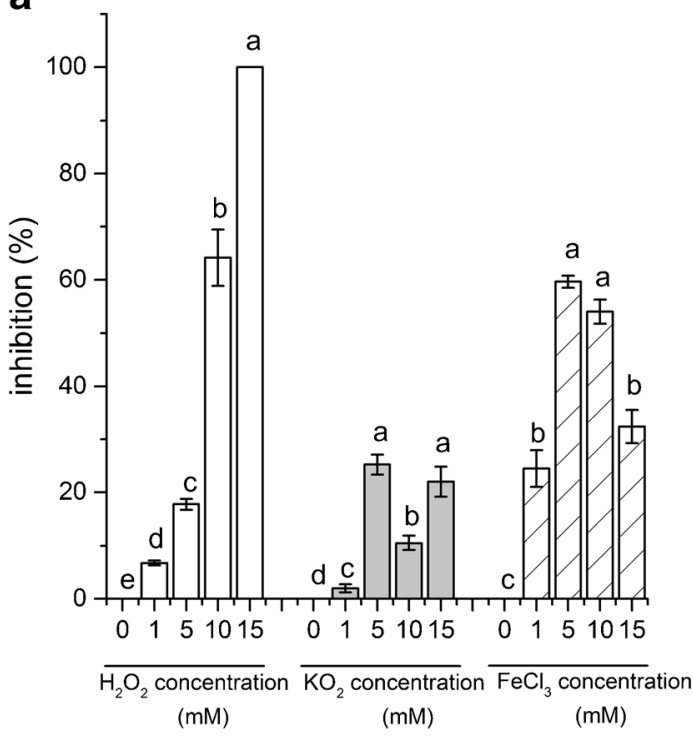

C

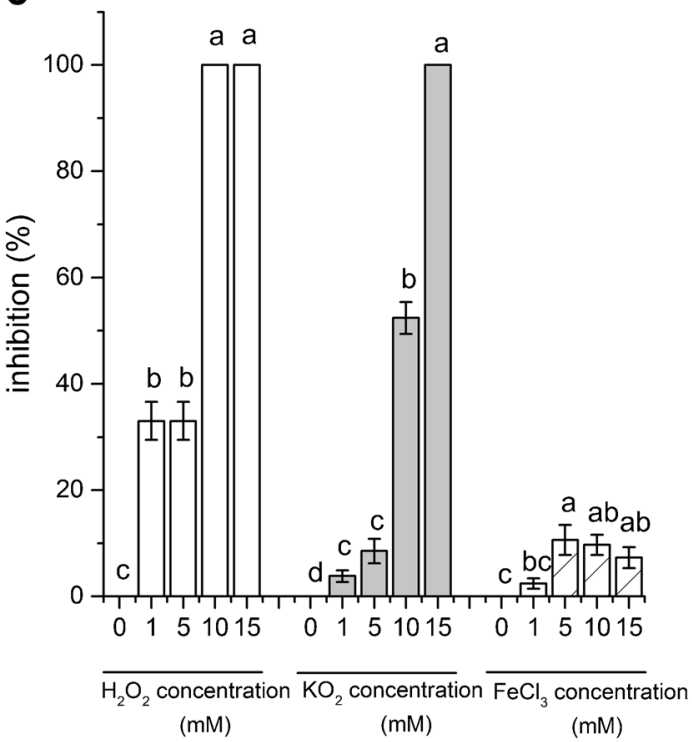

Fig. 1 Inhibition of F. oxysporum (a), R. solani (b), $H$. crustuliniforme (c), and L. bicolor (d) growth in vitro by hydrogen peroxide $\left(\mathrm{H}_{2} \mathrm{O}_{2}\right)$, a ROS generating compound $\left(\mathrm{KO}_{2}\right)$, and iron $\left(\mathrm{FeCl}_{3}\right)$. Data represent the average percentage $\pm \mathrm{SE}$ of growth inhibition relative to the control (growth in the absence of

In contrast, growth of the ectomycorrhizal fungi, $H$. crustuliniforme and L. bicolor, was only weakly affected by increasing concentrations of iron, while increasing concentrations of hydrogen peroxide had an increasingly negative effect on growth. The negative effect of increasing concentrations of the stress-inducing compounds on growth was most readily observed in mycorrhizal fungi where b

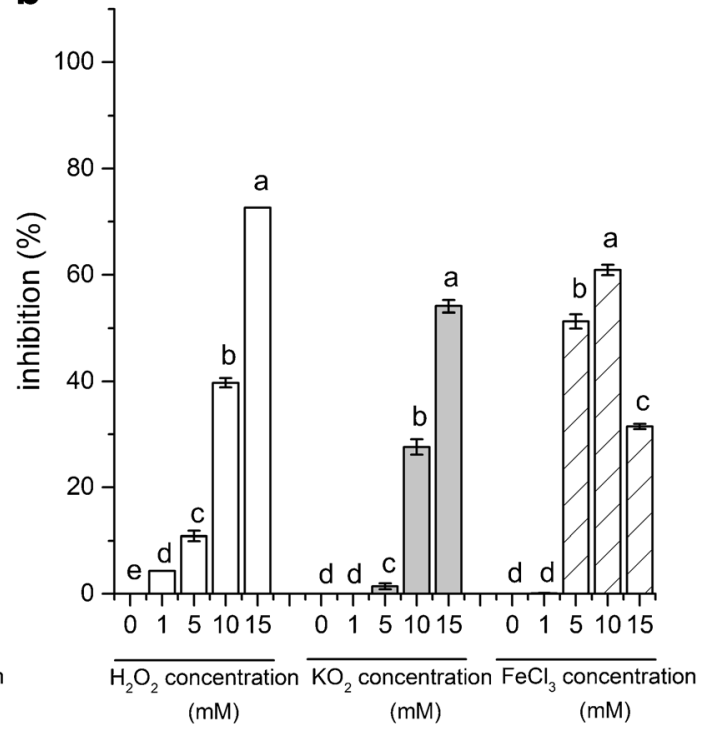

d

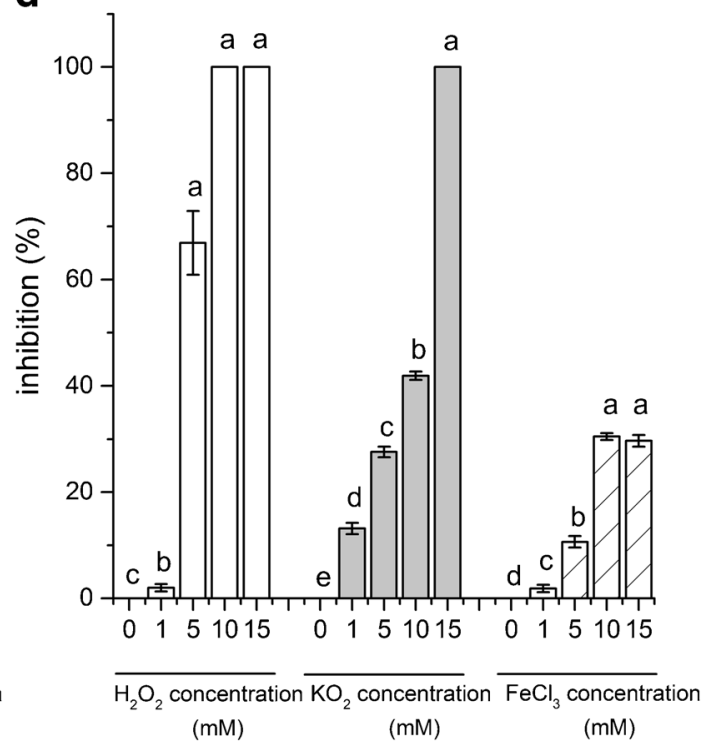

the tested compound) in the presence of increasing concentrations of hydrogen peroxide (white bars), superoxide anion radical (grey bars), and iron (hatched bars). Values marked with the same letter within one compound do not differ statistically (Tukey test, $P=0.05$ )

lower concentrations of the inhibiting agent $(1 \mathrm{mM}$ or $5 \mathrm{mM}$ ) were required to obtain similar levels of inhibition observed with pathogenic fungi. F. oxysporum and $R$. solani were most strongly inhibited at $10 \mathrm{mM}$ and $15 \mathrm{mM}$ concentrations of hydrogen peroxide $(P<0.001)$.

The growth of $L$. bicolor and $H$. crustuliniforme was strongly inhibited at $5 \mathrm{mM}$ hydrogen peroxide 
$(P<0.001)$. The growth of ectomycorrhizal fungi was completely inhibited at $10 \mathrm{mM}$ hydrogen peroxide, while the same concentration inhibited the growth of the pathogenic fungi $F$. oxysporum by $64 \%$ and $R$. solani by $40 \%$.

The reaction of the examined fungi to the presence of superoxide anion radicals was dependent on the species examined, and independent of the trophic strategy. The greatest level of growth inhibition among the necrotrophic fungi was observed in $R$. solani, while both species of ectomycorrhizal fungi were significantly inhibited.

\section{Discussion}

ROS are involved at the initial stage of a plant's response to necrotrophic pathogens and mycorrhizal fungus colonization. There is growing evidence that iron may also be one of the essential factors regulating plant-fungal interactions (Expert and O'Brian 2012; Johnson et al. 2007; Mucha et al. 2012, 2015). Whether the role of iron is linked to the role of ROS generation and whether a linkage of iron and ROS to host response is dependent on the trophic strategy of the invading fungus are still not well understood. In the present study, the pattern of iron accumulation in root cells of Scots pine (Pinus sylvestris) was strongly dependent on the trophic strategy of the invading fungus. The results also indicated that hydrogen peroxide was a stronger inhibitor of the growth of ectomycorrhizal growth in vitro than iron. In contrast, the in vitro growth of necrotrophic fungi was inhibited by both hydrogen peroxide and iron, indicating that the growth of trophically diverse fungi are differentially affected by stress-inducing compounds.

In the present study, fungi with contrasting trophic strategies all induced hydrogen peroxide accumulation in P. sylvestris roots. The pattern of accumulation of hydrogen peroxide, however, was dependent on species. More specifically, Scots pine roots infected with necrotrophic pathogens exhibit a different pattern of hydrogen peroxide accumulation than roots colonized by mycorrhizal fungi. ROS, including hydrogen peroxide, are induced in host tissues by invading fungi with different trophic strategies (Pellinen et al. 2002), but the function of the generated ROS could vary depending on the presence and concentration of other compounds. Notably, in the present study, iron was a significant factor that differentiated the response of necrotrophic vs. ectomycorrhizal strategy fungi. Given the redox potential of iron, hosts can utilize it to induce the production of hydroxyl radicals at the site of invasion that are very toxic to cells (Zwilling et al. 1999; Schaible and
Kaufmann 2004; Ong et al. 2006). Although previous studies have indicated that reactive oxygen species, including hydroxyl radicals, foster disease development by $R$. solani (Singh et al. 2011), the potential role of iron in the hydroxyl radical induction of disease development was not considered. Our present results revealed that an increase in the percentage of cells stained with $\mathrm{H}_{2} \mathrm{O}_{2}$ in root tissues infected with a necrotrophic fungus was also accompanied by an increase in the percentage of cells exhibiting $\mathrm{Fe}^{3+}$ staining. $\mathrm{Fe}^{3+}$ and $\mathrm{Fe}^{2+}$, in the presence of hydrogen peroxide, can catalyze the formation of hydroxyl radicals through the Fenton/Haber-Weiss reaction (Pierre and Fontecave 1999) and induce cell death. Cell death is essential for necrotrophic fungi as they can only acquire nutrients from dead tissues (Govrin and Levine 2000). Cell death has been reported to facilitate fungal establishment in $P$. sylvestris roots during the initial stage of invasion (Adomas et al. 2008; Mucha et al. 2014). In contrast to necrotrophic pathogens, the observed correlation between lower levels of hydrogen peroxide and iron accumulation may facilitate the colonization of roots by ectomycorrhizal fungi, as they rely on living tissues to acquire carbon (Nehls et al. 2010). The establishment of ectomycorrhizal fungi, however, does not always require or induce cell death (Baptista et al. 2007; Ragnelli et al. 2013; Mucha et al. 2014); even though an accumulation of $\mathrm{H}_{2} \mathrm{O}_{2}$ occurs. In this scenario, hydrogen peroxide restricts fungal growth rather than promoting fungal proliferation by killing plant tissues. Notably, hydrogen peroxide limited the growth of mycorrhizal fungi in vitro more than iron.

The current study provides evidence that the role of ROS accumulation in root tissues in response to colonization by mycorrhizal fungi may be less dependent on the presence of iron and its role in increasing the vulnerability of plant cells to $\mathrm{H}_{2} \mathrm{O}_{2}$. The higher correlation between ROS accumulation in Scots pine root cells and colonization by mycorrhizal fungi than with necrotrophic pathogens suggests that the activation of other processes is involved in the specific response to $\mathrm{H}_{2} \mathrm{O}$; including the induction of specific genes that actively restrict fungal growth. ROS have been reported to be induced at the initial stage of the interaction between plant and ectomycorrhizal fungi (Passardi et al. 2005) and to be a necessary factor in the establishment and maintenance of plant endophytes (Tanaka et al. 2006). Since ROS are known to induce defense-related genes, the sequence of events associated with defense reactions may inhibit the invasion of ectomycorrhizal fungi into deeper tissue layers (Peterson et al. 2004). The premise 
that hydrogen peroxide in host cells may prevent the further spread of ectomycorrhizal hyphae is supported by the fact that ectomycorrhizal fungi exhibit a greater sensitivity to hydrogen peroxide in vitro than necrotrophic fungi. Maintaining ROS levels may be an important parameter in establishing an equilibrium in mycorrhizal symbiosis (Rodriguez and Redman 2005). Therefore, the potential role of redox reactions and iron in the oxidative burst associated with plant root-ectomycorrhizal fungi interactions warrants further investigation.

Iron levels have been found to play an essential role in both fungal virulence and plant defense response (Dong et al. 2016; Expert and O'Brian 2012). The effect of iron and ROS production on fungal colonization has indicated that the role of iron is more important for the establishment of necrotrophic pathogens than ectomycorrhizal fungal species. Our present work provides evidence that iron dynamics play an important role in the interaction between root tissues of $P$. sylvestris and necrotrophic fungi. Iron accumulation was also shown to play an important role in determining the response of $P$. sylvestris roots to the pathogenic fungus, F. oxysporum (Ascomycota). The presence of available iron greatly enhances the virulence of Ascomycetes, possibly by enhancing their tolerance to $\mathrm{H}_{2} \mathrm{O}_{2}$ (Oide et al. 2006). Indeed, iron and other nutrients (e.g. $\mathrm{Zn}^{2+}$, $\left.\mathrm{Mn}^{2+}, \mathrm{Cu}^{2+}\right)$ known as reductants in redox reactions have a deleterious effect on the establishment of Fusarium species in plants (Ruiz et al. 2015; Dong et al. 2016), while mycorrhizal fungi provide iron to plants (Adeleke et al. 2012). Our current results indicate that iron availability is highly associated with the vulnerability of plant roots to necrotrophic pathogens.

Mucha et al. (2014) previously reported that the response of Scots pine to trophically diverse fungi is dependent on the root zone that is being invaded and that necrotrophic fungi preferentially colonize the meristematic zone. The preferential colonization of the meristematic zone of roots by the necrotrophic fungus, Fusarium oxysporum, is also supported by studies reported by Rodriguez-Galvez and Mendgen (1995) and Asiegbu et al. (1999). This pattern of colonization agrees with our findings in the current study that greater increases in $\mathrm{Fe}^{3+}$ and $\mathrm{Fe}^{2+}$ occurred in the meristematic zone of $P$. sylvestris roots in the presence of necrotrophic fungi. The observation that iron, when combined with ROS, form hydroxyl radicals that lead to cell death; this supports the premise that necrotrophic pathogen obtain nutrients after killing host tissues (Asiegbu et al. 1994; Mayer et al. 2001). Therefore, it is possible that disruption of cells in the meristematic zone of roots may be a mechanism that supports the invasion of host roots. The data obtained from the present study indicate that iron availability is highly correlated with the vulnerability of plant roots to necrotrophic pathogens.

\section{Summary}

The current study revealed that a significant increase in hydrogen peroxide in $P$. sylvestris root cortical cells infected with a pathogenic fungus is correlated with the accumulation of iron, Similarly, the ionic status of iron $\left(\mathrm{Fe}^{3+}, \mathrm{Fe}^{2+}\right)$ is trophic specific and potentially determines the ability of fungi to establish an infection. Moreover, the pattern of accumulation of different forms of iron in different root zones may alter how the oxidative burst is induced, as well as its functional role. Increases in hydrogen peroxide in the elongation zone would limit the ability of a mycorrhizal fungus to spread into deeper root tissues (stele). In contrast to ectomycorrhizal fungi, necrotrophic fungi preferentially colonize tissues in the meristematic zone of roots (Rodriguez-Galvez and Mendgen 1995; Mucha et al. 2014; Asiegbu et al. 1999; Mayer et al. 2001) to kill roots and make nutrients readily available. The current study demonstrated the accumulation of ferrous iron in the meristematic zone of root cells, especially in the presence of $F$. oxysporum. Changes in the distribution of different forms of iron and hydrogen peroxide are likely to impact the initial response of host tissues to necrotrophs vs. mycorrhizal fungi. Thus, strategies have evolved for maintaining or altering the balance between iron demand for metabolic processes, and its role in exacerbating ROS-induced cell death; and potentially determine the interactions of plant tissues with necrotrophic and mycorrhizal fungi.

Acknowledgements The research was financially supported by a grant (project no. DEC-2013/09/B/NZ9/01746) funded by the National Science Centre of Poland to Joanna Mucha and the Institute of Dendrology, Polish Academy of Sciences.

Author contributions JM obtained funding for the research, coordinated the research project, supervised the experiments, analyzed the data, and wrote the first draft of the manuscript. ANF participated in carrying out the experiment and contributed substantially to revisions. EG contributed substantially to revisions. TAP contributed substantially to revisions. MZ participated in the experiment and contributed substantially to the experimental design and revisions. 


\section{Compliance with ethical standards}

Conflict of interest The authors state that there are no conflicts of interest.

Human and animal rights This article does not contain any studies with human or animal subjects.

Open Access This article is distributed under the terms of the Creative Commons Attribution 4.0 International License (http:// creativecommons.org/licenses/by/4.0/), which permits unrestricted use, distribution, and reproduction in any medium, provided you give appropriate credit to the original author(s) and the source, provide a link to the Creative Commons license, and indicate if changes were made.

\section{References}

Adeleke, R. A., Cloete, T. E., Bertrand, A., \& Khasa, D. P. (2012). Iron ore weathering potentials of ectomycorrhizal plants. Mycorrhiza, 22(7), 535-544.

Adomas, A., Heller, G., Olson, Å., Osborne, J., Karlsson, M., Nahalkova, J., van Zyl, L., Sederoff, R., Stenlid, J., Finlay, R., \& Asiegbu, F. O. (2008). Comparative analysis of transcript abundance in Pinus sylvestris after challenge with a saprotrophic, pathogenic or mutualistic fungus. Tree Physiology, 28(6), 885-897.

Asiegbu, F. O., Daniel, G., \& Johansson, M. (1994). Defence related reactions of seedling roots of Norway spruce to infection by Heterobasidion annosum (Fr.) Bref. Physiologial and Molecular Plant Pathology, 45, 1-19.

Asiegbu, F. O., Johansson, M., \& Stenlid, J. (1999). Reactions of Pinus sylvestris (scots pine) root tissues to the presence of mutualistic, saprotrophic and necrotrophic microorganisms. Journal of Phytopathology, 147, 257-264.

Baker, C. J., \& Orlandi, E. W. (1995). Active oxygen in plant pathogenesis. Annual Review of Phytopathology, 33, 299-321.

Baptista, P., Martins, A., Pais, M. S., Tavares, R. M., \& Lino-Neto, T. (2007). Involvement of reactive oxygen species during early stages of ectomycorrhiza establishment between Castanea sativa and Pisolithus tinctorius. Mycorrhiza, 17, 185-193.

Dellagi, A., Segond, D., Rigault, M., Fagard, M., Simon, C., Saindrenan, P., \& Expert, D. (2009). Microbial siderophores exert a subtle role in Arabidopsis during infection by manipulating the immune response and the iron status. Plant Physiology, 150, 1687-1696.

Dong, X., Wang, M., Ling, N., Shen, Q., \& Guo, S. (2016). Effects of iron and boron combinations on the suppression of Fusarium wilt in banana. Scientific Reports, 6, 38944.

Eichhorn, H., Lessing, F., Winterberg, B., Schirawski, J., Kämper, J., Müller, P., \& Kahmann, R. (2006). A ferroxidation/ permeation iron uptake system is required for virulence in Ustilago maydis. The Plant Cell, 18(11), 3332-3345.

Expert, D. (1999). Withholding and exchanging iron: Interactions between Erwinia spp. and their plant hosts. Annual Review of Phytopathology, 37(1), 307-334.
Expert, D., \& O'Brian, M. R. (2012). Molecular aspects of iron metabolism in pathogenic and symbiotic plant-microbe associations. Springer Science \& Business Media.

Felle, H., Waller, F., Molitor, A., \& Kogel, K. H. (2009). The mycorrhiza fungus Piriformospora indica induces fast rootsurface $\mathrm{pH}$ signaling and primes systemic alkalinization of the leaf apoplast upon powdery mildew infection. Molecular Plant-Microbe Interactions, 22, 1179-1185.

Franza, T., Michaud-Soret, I., Piquerel, P., \& Expert, D. (2002). Coupling of iron assimilation and pectinolysis in Erwinia chrysanthemi 3937. Molecular Plant-Microbe Interactions, 15(11), 1181-1191.

Franza, T., Mahé, B., \& Expert, D. (2005). Erwinia chrysanthemi requires a second iron transport route dependent of the siderophore achromobactin for extracellular growth and plant infection. Molecular Microbiology, 55(1), 261-275.

Govrin, E. M., \& Levine, A. (2000). The hypersensitive response facilities plant infection by the necrotrophic pathogen Botrytis cinerea. Current Biology, 10, 751-757.

Greenshields, D. L., Liu, G., Feng, J. I. E., Selvaraj, G., \& Wei, Y. (2007). The siderophore biosynthetic gene SID1, but not the ferroxidase gene FET3, is required for full Fusarium graminearum virulence. Molecular Plant Pathology, 8(4), 411-421.

Haselwandter, K. (1995). Mycorrhizal fungi: Siderophore production. Critical Reviews in Biotechnology, 15(3-4), 287-291.

Ingestad, T. (1979). Mineral nutrient requirements of Pinus sylvestris and Picea abies seedlings. Physiologia Plantarum, 45, 373-380.

Johnson, L. (2008). Iron and siderophores in fungal-host interactions. Mycological Research, 112(2), 170-183.

Johnson, L. J., Steringa, M., Koulman, A., Christensen, M., Johnson, R. D., Voisey, C. R., Bryan, G., Lamont, I., \& Rasmussen, S. (2007). Biosynthesis of an extracellular siderophore is essential for maintenance of mutualistic endophyte-grass symbioses. In: Popay A. J., Thom E. R. (Eds). Proceedings of the sixth international symposium on fungal endophytes of grasses grassland research and practice series (No. 13, pp. 177-179). Dunedin: New Zealand Grasslands Association.

Liu, G., Greenshields, D. L., Sammynaiken, R., Hirji, R. N., Selvaraj, G., \& Wei, Y. (2007). Targeted alterations in iron homeostasis underlie plant defence responses. Journal of Cell Science, 120, 596-605.

Mayer, A. M., Staples, R. C., \& Gil-ad, N. L. (2001). Mechanism of survival of necrotrophic fungal plant pathogens in hosts expressing the hypersensitive response. Phytochemistry, 58, 33-41.

Mucha, J., Guzicka, M., Łakomy, P., \& Zadworny, M. (2012). Iron and reactive oxygen responses in Pinus sylvestris root cortical cells infected with different species of Heterobasidion annosum sensu lato. Planta, 236, 975-988.

Mucha, J., Guzicka, M., Ratajczak, E., \& Zadworny, M. (2014). Strategies utilized by trophically diverse fungal species for Pinus sylvestris root colonization. Tree Physiology, 34(1), 73-86.

Mucha, J., Budka, A., Kayzer, D., Guzicka, M., Łakomy, P., \& Zadworny, M. (2015). The origin of reactive oxygen during interaction of Pinus sylvestris root and Heterobasidion annosum sl-the linkage with the iron. European Journal of Plant Pathology, 143(2), 277-290. 
Nehls, U., Göhringer, F., Wittulsky, S., \& Dietz, S. (2010). Fungal carbohydrate support in the ectomycorrhizal symbiosis: A review. Plant Biology, 12(2), 292-301.

Oide, S., Moeder, W., Krasnoff, S., Gibson, D., Haas, H., Yoshioka, K., \& Turgeon, B. G. (2006). NPS6, encoding a nonribosomal peptide synthetase involved in siderophoremediated iron metabolism, is a conserved virulence determinant of plant pathogenic ascomycetes. The Plant Cell, 18, 2836-2853.

Ong, S. T., Ho, J. Z. S., Ho, B., \& Ding, J. L. (2006). Ironwithholding strategy in innate immunity. Immunobiology, 211(4), 295-314.

Passardi, F., Cosio, C., Penel, C., \& Dunand, C. (2005). Peroxidases have more functions than a Swiss army knife. Plant Cell Reports, 24(5), 255-265.

Pellinen, R. I., Korhonen, M. S., Tauriainen, A. A., Palva, E. T., \& Kangasjärvi, J. (2002). Hydrogen peroxide activates cell death and defense gene expression in birch. Plant Physiology, 130(2), 549-560.

Peterson, R. L., Massicotte, H. B., \& Melville, L. H. (2004). Mycorrhizas: Anatomy and cell biology. Wallingford, UK: CABI Publishing.

Pierre, J. L., \& Fontecave, M. (1999). Iron and activated oxygen species in biology: The basic chemistry. Biometals, 12, 195-199.

Ragnelli, A. M., Aimola, P., Maione, M., Zarivi, O., Leonardi, M., \& Pacioni, G. (2013). The cell death phenomenon during tuber ectomycorrhiza morphogenesis. Plant Biosystems - An International Journal Dealing with all Aspects of Plant Biology: Official Journal of the Societa Botanica Italiana, 148, 473482. https://doi.org/10.1080/11263504.2013.788575.

Ramanan, N., \& Wang, Y. (2000). A high-affinity iron permease essential for Candida albicans virulence. Science, 288(5468), 1062-1064.

Renshaw, J. C., Robson, G. D., Trinci, A. P., Wiebe, M. G., Livens, F. R., Collison, D., \& Taylor, R. J. (2002). Fungal siderophores: Structures, functions and applications. Mycological Research, 106(10), 1123-1142.

Rodriguez, R., \& Redman, R. (2005). Balancing the generation and elimination of reactive oxygen species. Proceedings of the National Academy of Sciences USA, 102(9), 3175-3176.
Rodriguez-Galvez, E., \& Mendgen, K. (1995). The infection process of Fusarium oxysporum in cotton root tips. Protoplasma, 189(1-2), 61-72.

Ruiz, J. A., Bernar, E. M., \& Jung, K. (2015). Production of siderophores increases resistance to fusaric acid in Pseudomonas protegens Pf-5. PLoS One, 10(1), e0117040.

Schaible, U. E., \& Kaufmann, S. H. (2004). Iron and microbial infection. Nature Reviews Microbiology, 2(12), 946-953.

Scheres, B., Benfey, P., \& Dolan, L. (2002). Root development. Arabidopsis Book, 40, 1-18.

Schrettl, M., Bignell, E., Kragl, C., Joechl, C., Rogers, T., Arst, H. N., et al. (2004). Siderophore biosynthesis but not reductive iron assimilation is essential for aspergillus fumigatus virulence. Journal of Experimental Medicine, 200(9), 1213-1219.

Singh, B. N., Singh, A., Singh, S. P., \& Singh, H. B. (2011). Trichoderma harzianum-mediated reprogramming of oxidative stress response in root apoplast of sunflower enhances defence against Rhizoctonia solani. European Journal of Plant Pathology, 131(1), 121-134.

Smith, M. A., Harris, P. L. R., Sayre, L. M., \& Perry, G. (1997). Iron accumulation in Alzheimer disease is a source of redoxgenerated free radicals. Proceedings of the National Academy of Sciences USA, 94, 9866-9868.

Snedecor, W., \& Cochran, W. G. (1967). Statistical methods (6th ed., pp. 327-329). Ames. The Iowa State University Press.

Tanaka, A., Christensen, M. J., Takemoto, D., Park, P., \& Scott, B. (2006). Reactive oxygen species play a role in regulating a fungus-perennial ryegrass mutualistic interaction. The Plant Cell, 18, 1052-1066.

Thordal-Christensen, H., Zhang, Z., Wei, Y., \& Collinge, D. B. (1997). Subcellular localization of $\mathrm{H}_{2} \mathrm{O}_{2}$ in plants. $\mathrm{H}_{2} \mathrm{O}_{2}$ accumulation in papillae and hypersensitive response during barley-powdery mildew interaction. The Plant Journal, 11, 1187-1194.

Zhang, R. Q., \& Tang, M. (2012). Role of hydrogen peroxide and antioxidative enzymes in Pinus tabulaeformis seedlings inoculated with Amanita vaginata and/or Rhizoctonia solani. European Journal of Plant Pathology, 134(2), 381-389.

Zwilling, B. S., Kuhn, D. E., Wikoff, L., Brown, D., \& Lafuse, W. (1999). Role of iron in Nramp1-mediated inhibition of mycobacterial growth. Infection and Immunity, 67(3), 1386-1392. 